\title{
Correspondence
}

\section{Radiation in cardiology}

Sir,

Since the publication of our editorial in the British Heart fournal (1986;55:421-2) proposed regulations on the protection of patients from radiation have been circulated to interested parties by the Department of Health and Social Security. ${ }^{1}$ These proposals will enshrine the 1984 European Economic Community directive Radiation Protection of Persons Undergoing Medical Examination or Treatment ${ }^{2}$ as British law. To achieve an ALARA (as low as reasonably achievable) dose to the patient now becomes not only desirable but also a legal requirement. All medical workers in radiation must be either qualified-that is radiologists or radiographers - or undergo a simple course of training in the essential elements of good radiological procedure as set out in a new guide to good practice.

The regulations are expected to become law by the end of this year and they have implications not only for cardiologists in training but also for those who are established in the specialty.

M J Raphael, National Heart Hospital, London.

N E Tomlinson

Department of Radiological Sciences, Guy's Hospital Medical School, London.

\section{References}

1 The Ionising Radiations (Protection of Persons Undergoing Medical Examination or Treatment) Regulations 1986. Draft statutory instruments 1986 health and safety $\mathrm{ACl} / \mathrm{I} 1-6$.

2 Radiation protection of persons undergoing medical examination or treatment. EEC Directive $84 / 466$ / Euratom.

\section{Notices}

\section{British Cardiac Society}

The Annual General Meeting for 1987 will take place in Dundee on 8 and 9 April 1987, and the closing date for receipt of abstracts was 6 January 1987 .

The Autumn Meeting will be held at the Wembley Conference Centre, London, on 24 to 26 November 1987, and the closing date for receipt of abstracts will be 10 July 1987 .

\section{Argentine Society of Cardiology}

An International Congress " 50 th Anniversary of the Argentine Society of Cardiology" will be held in $\triangle$ Buenos Aires on 11 to 16 October 1987. Further $\frac{D}{O}$ details from Secretaria, Azcuenaga 980/86, $1115 \fallingdotseq$ Buenos Aires, Argentina. 